\title{
A POTENCIÁLIS VÁROSOK EGÉSZSÉGÜGYI INFRASTRUKTÚRÁJÁNAK ÉS ELLÁTOTTSÁGÁNAK TERÜLETI SAJÁTOSSÁGAI
}

\author{
(Regional characteristics of the health care infrastructure and provisionof \\ some potential towns)
}

\section{PÁL VIKTOR}

A magyarországi egészségügyi rendszer területi sajátosságaival, különösen annak egyenlỏtlenségeivel több munka foglalkozott már a hazai társadalomföldrajzban (Orosz 1985, 1989, 1993) A vizsgálatok során hamar felszínre bukkantak a magyar egészségügyi rendszer legfontosabb területi problémái: a területileg túlkoncentrált kórházhálózat, a háttérbe szorított alap- és szociális ellátás, centralizált krónikus osztályok, a Budapestvidék, illetőleg a falu-város dichotómia ${ }^{1}$. Ez utóbbi egyenlőtlenség a szakellátáshoz való hozzáférhetőség nyilvánvaló különbségén túl az alapellátás eltérésében is tetten érhetỏ (Orosz 1988). Valószínúsíthető, hogy a falu-város egyenlötlenség mellett a falvak között is kimutathatók fejlettségbeli, ellátottságbeli és szerepkörbeli különbözöségek az egészségügyi rendszer vonatkozásában. Ez egyértelmủen következik falurendszerünk inhomogenitásából. Elképzelhető azonban, hogy még a más szempontok alapján nagyjából azonos fejlettségi szintủ, azaz közel homogẻnnek tekinthető falvak egészségügyi rendszere között is találhatunk regionális különbségeket.

A feltevés egy átfogóbb kutatás keretében alakult ki, melyhez kapcsolódóan egyedi módszert kellett kidolgozni, szem előtt tartva az összehasonlíthatóság szempontjait. Ez a módszer - eredeti funkciója mellett - alkalmas a feltevés igazolására is. Ennek lényege, hogy a már elözöleg kiválasztott települések egészségügyi rendszerét azonos szempontok szerint értékeltem, egy 1-tól 100-ig terjedő skálán egyetlen számértékben minősítettem, rangsoroltam, majd csoportokra osztottam. Az így kapott elkülönített csoportokat térképen ábrázolva láthatóvá váltak a települések egészségügyi rendszerének regionális differenciái.

Az egészségügyi rendszer integrált mutatója négy mutatócsoportból tevődik össze. $\mathrm{Az}$ elsō mutatócsoport a település egészségügyi infrastruktúrájának fejlettségi szintjét jelzi. Az egészségügyi infrastruktúrát a településen található egészségügyi intézmények alapján határoztam meg. Ez alapján három további alszempontot vettem figyelembe: az alapellátás intézményeinek fejlettségét, a szakellátás intézményeinek fejlettségét és a sürgösségi ellátást. Az alapellátás részének tekintettem a gyógyszertárat, a háziorvosi rendelõt, a fogorvosi rendelöt, az ezeket összefogó intézményeket (egészségügyi központ, egészségház, egészségügyi szolgálat, egészségvédő intézet, egészségügyi komplexum stb.), a védőnői szolgálatot, a családsegitő szolgálatot és az anya- és gyermekvédelmi tanácsadó szolgálatot. A szakellátás részének a településen található rendszeres vagy időszakos, általában alapszakmás szakrendeléseket, különböző laboratóriumokat, rendelöintézeteket, a kórházak osztályainak járó beteg szakambulanciáit, a kórházakat, a különbözỏ gondozókat, intézeteket tekintettük. Ide tartozik az olyan intézmény is, amely valamilyen más településen található intézmény részét képezi, azaz ún. "leosztott 
funkcióval" bír. A sürgősségi ellátáshoz a mentőảllomásokat és az állandó orvosi ügyeletet vettem. Előny volt az egyes elemek magasabb bonyolultsági foka és a magasabb hierarchiaszintủ intézmények megléte. Az összes mutatócsoportból ezt tekintettem a legfontosabbnak, az összes 100 egységből maximálisan 40 -et kaphatott az illetó település. Részletesebb bontásban:

- az alapellátás fejlettsége

- a szakellátás és a sürgősségi ellátás fejlettsége

max. 11 pont

$\max .29$ pont

A mutatócsoport kialakításánál igen nagy problémát jelentett, hogy az egészségügyi infrastruktúrának csak egyetlen elemét sikerült felmérni, az intézményhálózatot. Bár kétségtelen, hogy az intézmények megléte az egyik legalapvetőbb infrastrukturális feltételrendszer, hasznos lett volna a személyi háttér, a müszerezettség és az igénybevétel feltárása is. A személyi háttér azonban sokkal flexibilisebb kategória az intézménynél, ezért nem mérhetô megbízhatóan, a müszerezettség pedig egyrészt statisztikailag nehezen hozzáférhetó, másrészt nagyon bonyolulttá tette volna a mutatókat. Ugyanez mondható el az igénybevételről is: adatforrásai az intézmény belsỏ nyilvántartásának részei, így sok esetben az orvosi titoktartás szabályai alá esnek. Problémás kérdés annak eldöntése is, hogy mely intézmények sorolhatók az alapellátás és melyek a szakellátás körébe, továbbá, hogy az egyes intézmények milyen helyet foglalnak el az egészségügyi hierarchiában² .

A második mutatócsoport az egészségügyi ellátottság, amely kétféleképpen értelmezhetơ. Egyrészt a település egészségügyi ellátottságaként, másrészt az ott élők ellátottságaként. A módszerben az ellátottságot a településen élók egészségügyi ellátottságaként értelmeztem. Elsősorban arra a kérdésre kerestem a választ, hogy földrajzi értelemben milyen az egyes szolgáltatások elérhetösége magán a településen és azon kívül. Kiemelt tényezö a szakellátás, azon belül is az egyre specializáltabb, a hierarchiában magasabban elhelyezkedő szolgáltatások elérhetősége (nem csak alapszakmás szakrendelések, rendelöintézetek, kórházak, klinikák). Ez alapján a mutatócsoporton belül vizsgáltam az egy háziorvosra jutó lakosok számát, az egy gyógyszertárra jutó lakosok számát, a legközebbi rendelóintézettöl, kórháztól, klinikától, mentöállomástól való távolságot (közúton km-ben kifejezve). A "távolsághatás-törvény" kifejezésének ez ugyan nem a legkorszerúbb, ám a legjobban hozzáférhetőbb és legkönnyebben kezelhető módja. Minél kevesebb lakos jut egy orvosra, egy gyógyszertárra, illetőleg minél közelebb vannak a speciálisabb szolgáltatások, annál kedvezőbb a településen élök egészségügyi ellátottsága.

A mutatócsoport a második legfontosabbnak tartott tényezö, ezért maximálisan 30 egységet érhetett el egy település. Ahol: minden egyes tényezö: $\max .5$ pont.

A harmadik mutatócsoport a település egészségügyi infrastruktúrájának térségi vonzását fejezte ki, melyre maximálisan 20 pont volt adható. Az elbírálásnál számításba kellett venni, hogy müködik-e a településen térségi ügyeleti rendszer, található-e a közelben ugyanolyan vagy magasabb hierarchiájú intézmény, illetve egészségügyi intézményei ellátnak-e szakfeladatokat. A legnagyobb problémát ennél a tényezőnél az adatok hozzáférhetetlensége jelenti ${ }^{3}$.

A negyedik mutatócsoport a település egészségügyi infrastruktúrájának térségen kivvüli (megyei, országos) vonzását vizsgálja. A tényezö maximálisan 10 ponttal értékelhetö, meghatározása viszonylag egyértelmú. 


\section{1. ÁBRA}

A vissgall telepiulesck elhelyezkedese rangsorban

(The potential lowns in Hungary by rank)

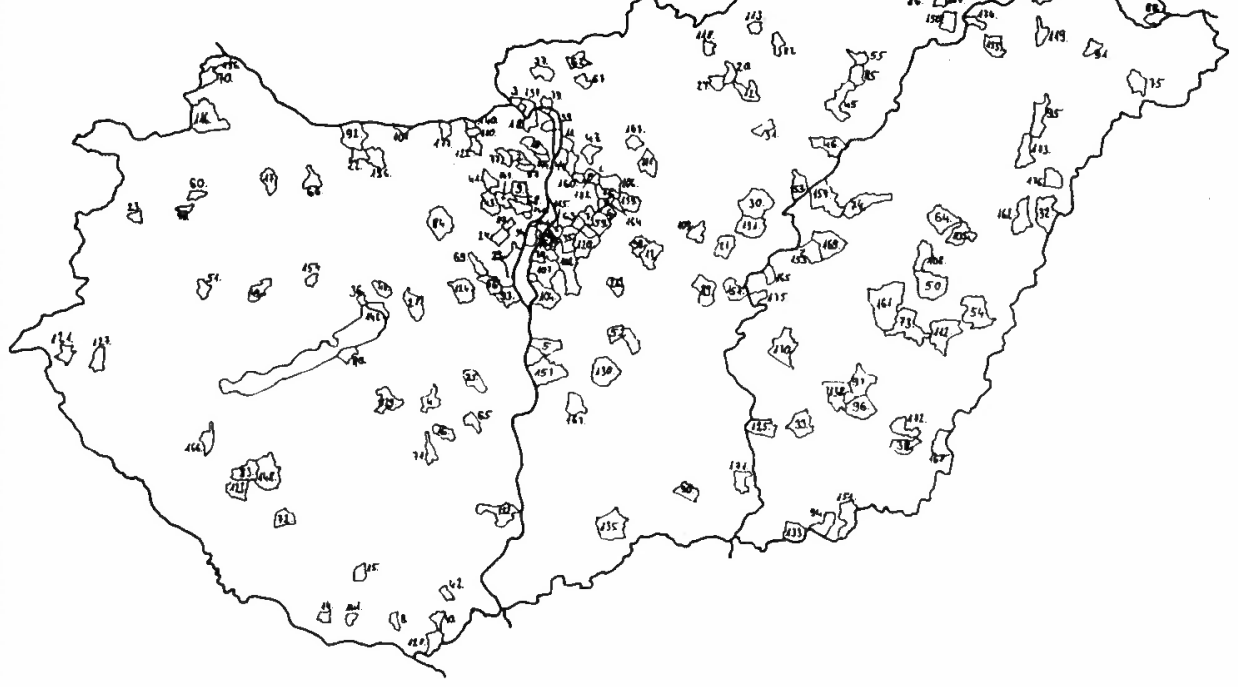

2. ÁBRA

A falvak egússségingyi ellátouságának értékè léx

(The villages by the health services - main groups)

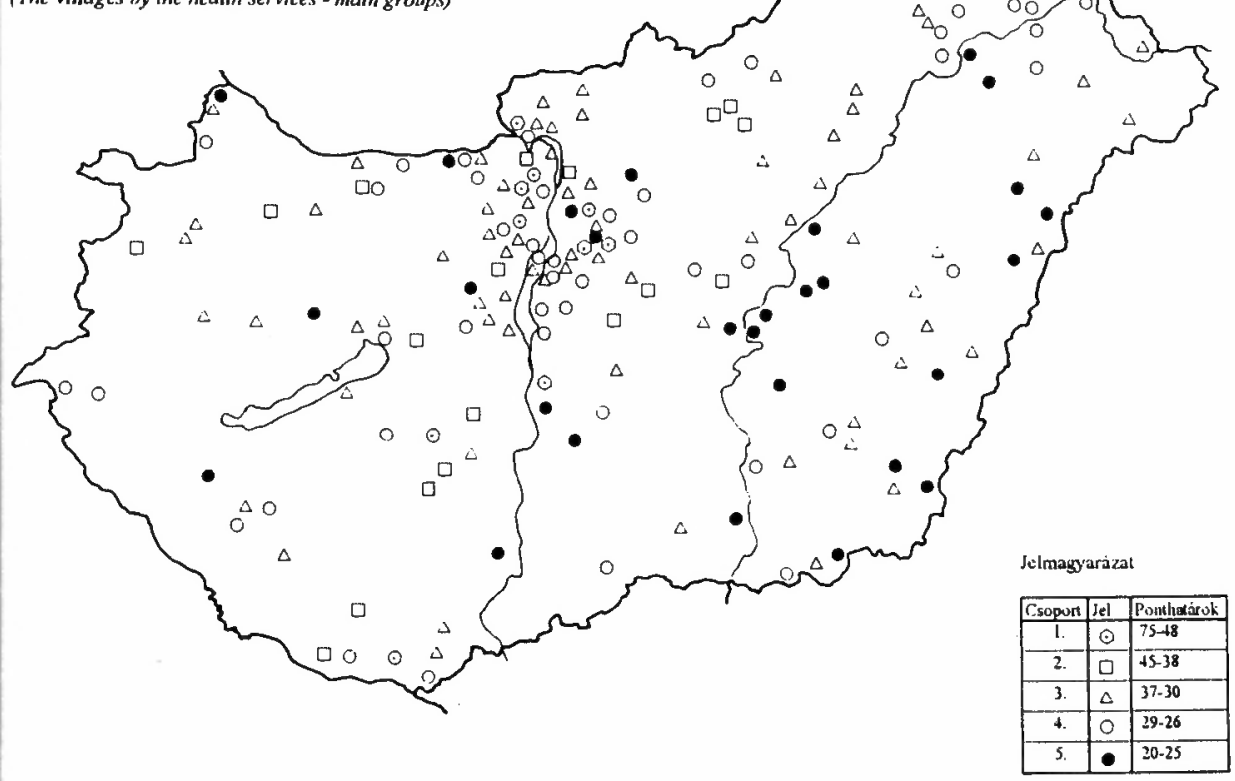


Az egyes mutatócsoportok eredményeinek vizsgálatakor általánosságban megállapítható, hogy az egészségügyi infrastruktúra fejlettsége a legdifferenciáltabb, az egészségügyi ellátottság viszonylag homogén képet mutat, amely az ország kis területéböl és az alapellátás decentralizáltságából következik, a térségi egészségügyi szerep differenciált és végül az országos egészségügyi szerep rendkívül polarizált. A végső sorrendet legjobban az első és a harmadik mutatócsoport követi, a második nem befolyásolja a sorrendet, míg az utolsó teljesen önálló életet él.

A részpontszámok egyesítésével kialakult összpontszámok eredményeként létrejött a vizsgált települések sorrendje ( 1 . ábra), melyben a magasabb pontértéküek vannak kedvezöbb helyzetben egészségügyi szempontból. A legmagasabb pontszám 75 , a legalacsonyabb 20 volt, ami igen nagy differenciákat takar. Igen kevés azonban a maximális és minimális értékek közelében lévő települések száma. Az összpontszám szerinti arányos eloszlás alapján 5 csoportot alakítottam ki, melyben az elsö csoport tartalmazza a legtöbb pontot elért településeket. (2. ábra)

$\mathrm{Az}$ elsô csoportba tartozó települések (2. ábra) elemszáma mindössze $10 \mathrm{db}, \mathrm{az}$ összesnek alig 6\%-a. A minimális pontérték 48 , a maximális 75 , így a csoport tartománya 27 egység, az egyes települések értékeinek csökkenése nagyjából egyenletes. Az ide tartozó települések mindegyike magas értéket produkált az egészségügyi infrastruktúra fejlettségében, $70 \%$-uk térségi, $60 \%$-uk valamilyen fokú országos szerepkört is betölt. Területi elhelyezkedésük sajátossága a koncentráció: 70\%-uk a budapesti agglomerációban vagy környezetében található. Sajátos "anomália" Pincehely kórháza és Harkány gyógyfürdőjére épülö szanatóriumai miatt. Ez utóbbi komoly országos vonzeröt jelent. A többi település egyértelmüen Budapest közelségének és/vagy az ún. "leosztott funkcióinak" köszönheti előnyös helyzetét.

A második csoportba $18 \mathrm{db}$ település sorolható, amely az összesnek közelítöleg 10\%-a (2. ábra). A minimális pontszám 38, a maximális 45 , így a csoport települései mindössze 7 egység tartományban mozognak. Ez már jelzi, hogy a csoportok közepe felé haladva egyre nő a homogenitás. $22 \%$-uk produkált viszonylag magas értéket az egészségügyi infrastrukturális fejlettségben (10-14 pont), 55\%-uk igen erős vonzást fejt ki a környezetére, de csupán 1 rendelkezik országos vonzerövel. Területi elhelyezkedésükben figyelemreméltó jelenség, hogy csupán 2 db található a budapesti agglomerációban, a Tiszántúlon egy sem és nagyon kis szám $(3 \mathrm{db})$ jellemzö az Alföld egészére is. Ez a három település is az Alföld észak-nyugati részén fekszik. A kategória településeinek zöme így a Dunántúlon helyezkedik el.

A harmadik csoport elemszáma a legnagyobb: $72 \mathrm{db}$ település sorolható ide, mely az összesnek bö $40 \%$-a (2. ábra). A csoport települései 30 ás 37 pont között mozognak, így a legrosszabb és a legjobb értéket elért között mindössze 7 egység a különbség. Ennek egyértelmü következménye a homogenitás: a csoporton belül rangsorolni szinte lehetetlen. Az egészségügyi infrastruktúra fejlettsége nagyjából azonos (egy kivétel), s mindössze 5 település $(6 \%)$ ugrik ki térségi vonzásával, azok is többnyire környezetük fejletlensége miatt. Közepesnek ítélhető országos vonzása is mindössze 5 településnek $(6 \%)$ van. Térbeli elhelyezkedésük egyrészt koncentrálódik a budapesti agglomerációban és tágabb környezetében ( $38 \%$-uk található ezen a viszonylag kis területen $)^{4}$, másrészt a Tiszántúlon $(20 \%)$ és Észak-Magyarországon szórtan helyezkedik el.

A negyedik csoport is viszonylag sok települést tartalmaz: 50 -et (28\%). A minimális pont értéke 26, míg a maximálisé 29 (2. ábra). Ezáltal ez tekinthetỏ a leghomogénebb csoportnak mindössze 4 egység differenciával a szélső értékek között. Mindegyik 
alszempontra igaz ez az egysíkúság, egyik sem rendelkezik országos vonzással és a gyenge térségi szerepkör is összhangban van a fejletlen egészségügyi infrastruktúrával. Területi koncentrációja a budapesti agglomeráció dél-keleti, Alfơld felé eső része, KomáromEsztergom megye északi része és Északkelet-Magyarország.

Az ötödik csoport rendelkezik a legrosszabb paraméterekkel, 27 települést számlál (16\%). A minimális ás maximális pontértékek: $20-25$. A csoport minőségi mutatóira nézve teljesen homogén (2. ábra), azonban területi elhelyezkedésében kb. 74\%-ban az Alföldre koncentrálódik.

A vizsgált települések egészségügyi rendszerének területi egyenlőtlenségeit áttekintve ossszegzésképpen megállapítható, hogy a hipotézisben felvetett probléma, mi szerint a fejlettségben egymáshoz viszonylag közelálló települések is mutatnak területi differenciákat, az egészségügyi rendszer szempontjából - az alkalmazott módszer eredményei alapján beigazolódott. Érdekes sajátosság, hogy még egy ilyen kis mintát és csupán egyetlen tényezőt (az egészségügyet) alapul véve is kirajzolódnak az ország egyes régióira jellemző sajátosságok. Ezek közül érdemes kiemelni a budapesti agglomeráció ellentmondásos jellegét és az Alföld egyértelmúen hátrányos helyzetét .

\section{Jegyzetek}

' Az egészségugy terulleti problémáira a Kormány Egészségügyi Programja is kitér az egészségügyi ellátás alapvetỏ problémái kőzơtt

${ }_{2}^{2}$ Mivel az egészségügy szabályozása átmeneti szakaszban van, ezért sokszor maga az orvosi szakma sem tudja pontosan definiálni a fenti fogalmakat. Gyakran a települések - tơrvényi szabályozás hiją̉n - a legküloỏnbözőbb elnevezésekkel látják el intézményeiket, melyekrỏl így szinte lehetetlen eldơnteni, hogy valójában melyik hierarchiaszintbe és az ellátás milyen kơrébe sorolandók.

3 pl. egy intézmény tényleges vonzása csupán a betegkartonok részletes elemzése során lenne kimutatható

4 A harmadik csoportba esỏ telepulések tơmörülése a budapesti agglomerációban különơsen a budai oldalon figyelhetó meg (7. melléklet)

\section{Irodalom}

A Kormány 1 107/1994.(XI.23) Korm. határozata a Kormány egészségùgyi cselekvési programjáról

Magyarország Nemzeti Atlasza (1989) Budapest. Kartográfiai Vállalat

Meditel (1994) Bp. Meditel KFT 1995.

Megyei Statisztikai Évkönyv 1994-röl KSH Megyei Igazgatóságok 1995.

Orosz É. (1985) Az egészségügyi infrastruktura területi külőnbségeinek vizsgálata. MTA RKK Eredményei 1. Pécs

Orosz É. (1988) A falvak egészségùgyi ellátása - az egészségügy és a közigazgatás rendszerében - A falu 22-28. 0 .

Orosz É. (1989) Az egészségügy teruleti egyenlơtlenségei - az újraérteimezés szükségességéről - Tér és Társadalom 3. 3-19. o.

Orosz É. (1993) A magyar egészségügy területi egyenlötlenségei. -Társadalmi és területi egyenlötlenségek Magyarországon. (szerk. Enyedi Gy.) Közgazdasági és Jogi Kơnyvkiadó, Budapest.

Szervezetek, intézmények belsố adatszolgáltatása 


\section{Abstract}

Several works of Hungarian social geography have already dealt with the regional particularities of the system of health care in Hungary, especially with its disequilibria. During the surveys, the most significant regional problems of the Hungarian health care system were very soon explored: A hospital network over-concentrated in certain regions, neglected basic and social care, centralised chronic departments in the hospitals, also, the Budapest-countryside and the village-town dichotomy. This disequilibrium can be seen, apart from the evident differences in the provision of specialised treatments, in the availability of basic health care, as well.

Villages too are very likely to demonstrate differences in the level of development, provision and functions in the health care system. It is even probable, however, that we can find regional differences in the state of health care between villages at more or less the same level of development from other aspects, i.e. in villages which can almost be considered as homogeneous.

This concept appeared while carrying out a more comprehensive research. To check the appropriateness of this, an individual research method should be elaborated, taking the aspects of comparability into consideration. 